\title{
EFEKTIVITAS PUPUK ORGANIK CAIR KEONG MAS PADA PERTUMBUHAN DAN HASIL TANAMAN PADI
}

\section{THE EFFECTIVENESS OF THE MASK LIQUID ORGANIC FERTILIZER ON THE GROWTH AND RESULTS OF RICE PLANTS}

\author{
Sulfianti $^{{ }^{*}}$, Miming Berlian ${ }^{1}$, Eko Priyantono ${ }^{1}$ \\ ${ }^{1}$ Program Studi Teknologi Pengolahan Hasil Bumi, Politeknik Palu \\ Jl. Sinar Kemuning 1A Bumi Roviga, Palu 94119, Indonesia
}

\begin{abstract}
ABSTRAK
Penelitianinibertujuan untuk mengkaji efektifitas pupuk organik cair keong mas terhadap pertumbuhan dan hasil tanaman padi.Penelitiandilaksanakan pada bulan Mei sampai November 2018 di Desa Sidondo III Kecamatan Sigi Biromaru Kabupaten Sigi. Penelitian ini dilakukan dalam 2 tahap, tahap pertama adalah pembuatan pupuk organik cair menggunakan Rancangan Acak Lengkap dengan 4 perlakuan yaitu A (Penambahan cangkang keong mas), B (penambahan daging keong mas), C (penambahan cangkang+daging keong mas) dan $\mathrm{D}$ (tanpa penambahan keong mas). Tahap kedua adalah aplikasi pupuk organik cair setiap perlakuan di lahan persawahan. Setiap perlakuan diulang 4 kali sehingga terdapat 16 unit percobaan. Hasil penelitian menunjukkan bahwa perlakuan dengan penambahan cangkang+daging keong mas memberikan hasil tertinggi terhadap kandungan $\mathrm{N}, \mathrm{P}, \mathrm{K}$ pupuk cair dibandingkan perlakuan lainnya. Perlakuan Cangkang+daging keong mas nyata meningkatkan pertumbuhan dan hasil tanaman padi.
\end{abstract}

Katakunci: Pupuk Organik Cair, Keong Mas, Tanaman Padi

\section{ABSTRACT}

This study aims to examine the effectiveness of golden snail organic liquid fertilizer on the growth and yield of rice plants. The study was conducted in May to November 2018 in Sidondo III village, SigiBiromaruSubdistrict, Sigi Regency. This research was conducted in 2 stages, the first stage was making liquid organic fertilizer using a completely randomized design with 4 treatments, namely A (addition of golden snail shell), $B$ (addition of golden snail meat), $C$ (addition of shells + golden snail meat) and D ( without the addition of goldensnails). The second stage is the application of liquid organic fertilizer for each treatment in rice fields. Each treatment was repeated 4 times so that there were 16 experimental units. The results showed that the treatment with the addition of golden snail shell + meat gave the highest yield to the content of $N, P, K$ liquid fertilizer compared to other treatments. The treatment of shells + mas snail meat significantly increases the growth and yield of rice plants.

Keywords: Liquid Organic Fertilizer, golden snail, Rice

\section{Pendahuluan}

Kebiasaan masyarakat Indonesia mengkonsumsi nasi sebagai makanan pokok menjadikan padi sebagai komoditas pertanian yang strategis dan menjadi tulang punggung perokonomian di Indonesia. Komoditi ini sangat berperan dalam ketahanan pangan, sehingga

\footnotetext{
${ }^{*}$ Penulis Korespondensi

E-mail: sulfiantisulfi@yahoo.com

Telp: +62-853-9742-1491
}

ketersediaan beras harus mampu memenuhi kebutuhan masyarakat. Kekurangan penyediaan beras di Indonesia akan menimbulkan dampak yang cukup besar bagi keberlanjutan kehidupan masyarakat. Olehnya itu pemerintah memberikan perhatian khusus dalam upaya peningkatan produksi tanaman padi. Namun, dalam membudidayakan tanaman banyak factor yang mempengaruhi hasil yang dicapai, kadangkala tidak sesuai dengan hasil yang diinginkan. Salah satu factor tersebut adalah Organisme Pengganggu Tanaman(OPT) salah satunya adalah 


\section{Jurnal Agrotech 8 (2) 56-61}

keong mas. Keong mas berdiameter1,5-2,5 cm dapat menyebabkan kerusakan berat pada tanaman sejak hari pertama sampai ketiga, kerusakan tanaman dapat mencapai lebih dari 97\%. Keong mas yang berukuran panjang $4 \mathrm{~cm}$ lebih ganas, karena dapat merusak tanaman padi yang ditanam pindah maupun tebar langsung (Arsyadana, 2014).

Keong mas merupakan ancaman bagi petani, namun ancaman tersebut dapat menjadi sahabat petani apabila dikelola dengan baik. Keong mas dapat lebih bernilai ekonomis dan ekologis apabila dijadikan pupuk organik, selain mengurangi dampak kerusakan akibat hama ini, pengolahan menjadi pupuk organik cair akan memperbaiki kualitas tanah serta tidak mencemari lingkungan dan dapat menambah pendapatan petani atau mengurangi biaya produksi petani terutama dalam hal penyediaan pupuk.

Pupuk organik merupakan isu global saat ini mengingat akan pentingnya pemenuhan kualitas lingkungan hidup sebagai bagian dari pemenuhan kesejahteraan hidup yang lebih layak. Pupuk organik menawarkan solusi yang lebih ramah lingkungan, walaupun manfaatnya tidak segera terlihat seperti pupuk anorganik, namun penggunaan secara terus menerus dapat memberikan manfaat yang berkesinambungan terhadap kesuburan tanah dan kesehatan lingkungan.

Dari permasalahan yang ada, kami mencoba menggagas suatu strategi pembuatan pupuk organik cair dari bahan-bahan yang dianggap limbah dan terdapat banyak di masyarakat. Penelitian pupuk organik cair berbahan dasar limbah pasar telah dilakukan sebelumnya, namun hasil yang diperoleh belum memperlihatkan hasil yang begitu optimal, pada penelitian sebelumnya Sulfianti (2013) melaporkan penelitian pupuk organik cair dengan bahan dasar limbah pasar (sayur dan buah afkiran) menghasilkan kandungan $\mathrm{N}$ sebesar 3,40\%, P sebesar 0,70\%, dan K sebesar $1,13 \%$, pada fermentasi anaerob. Olehnya itu pada penelitian ini akan ditambahkan keong mas sebagai sumber kitin dan sebagai sumber mikroorganisme yang dapat meningkatkan kandungan hara pupuk organik cair dan diharapkan dapat memperbaiki kualitas pupuk .

\section{Metode Penelitian}

Penelitian dilaksanakan pada bulan Mei sampai November 2018 di desa Sidondo III
e-ISSN : 2621-7236

p-ISSN : 1858-134X

Kecamatan Sigi Biromaru Kabupaten Sigi. Penelitian ini dirancang menggunakan Rancangan Acak Lengkap dengan 4 perlakuan yaitu penambahan cangkang keong mas, penambahan daging keong mas, penambahan cangkang+daging keong mas dan tanpa penambahan keong mas. Setiap perlakuan diulang 4 kali sehingga terdapat 16 unit percobaan. Penelitian ini dilakukan dalam beberapa tahap yaitu, tahap pertama adalah a) Pembuatan pupuk organik cair, buah-buahan dan sayuran afkiran dicacah untuk memperkecil ukurannya $(0,5 \mathrm{~mm})$ lalu dimasukkan ke dalam ember fermentasi, dicampur dengan bahan organik cair (urin sapi dan air kelapa) yang telah ditambahkan gula dan Em4, lalu ditambahkan keong mas sesuai perlakuan kemudian ember ditutup rapat dan dibiarkan mengalami fermentasi selama 15 hari. b) Tanah sebelum diolah digenangi air (jenuh) sekitar 3 hari, kemudian dibajak sedalam 20$25 \mathrm{~cm}$ setelah itu didiamkan 3 hari. Selanjutnya lahan digenangi air sedalam 3-5 $\mathrm{cm}$, dipupuk dengan kotoran sapi dosis 20 ton ha ${ }^{-1}$, kemudian digaru sebagai pembentukan lumpur dan perataan, genangan air kemudian dikurangi (sekitar $1 \mathrm{~cm}$ ), diratakan lagi (digaru), diakhiri dengan pembuatan petakan berukuran $3 \mathrm{~m} \times 3 \mathrm{~m}$. c). Penanaman tanaman padi dimulai dengan proses penyemaian di lahan persemaian, setelah bibit berumur 28 hari, bibit dipindahkan dan ditanam 4 bibit satu tancap (lubang tanam) dengan jarak tanam $30 \times 30 \mathrm{~cm}$. d) Pupuk diaplikasikan pada tanaman setelah tanaman berumur 10 HST, 20 HST, 30 HST, 40 HST, 50 HST, 60 HST, 70 HST dan 80 HST. Pupuk disemprotkan pada tanaman padi dengan dosis $300 \mathrm{ml} \mathrm{/} 11$ air. e). Pemeliharaan tanaman meliputi penyiangan (saat tanaman berumur 10, 20, 30, dan 40 HST secara manual dengan cara gulma yang tumbuh dicabut, penyiangan dilakukan sebelum aplikasi pupuk, sebelum disiang genangan ditinggikan sekitar $1-2 \mathrm{~cm}$ ), pengaturan air (sampai umur 10 HST kondisi sawah macak-macak; saat umur 10, 20, 30, dan 40 HST genangan ditinggikan dan air dibiarkan turun hingga macak-macak), kondisi tersebut dipertahankan hingga fase pembungaan dan pengisian bulir. Pada fase pematangan bulir sampai panen (96- 105 HST) sawah dikeringkan sehingga pematangan bulir padi cepat dan seragam. Panen dilakukan 


\section{Jurnal Agrotech 8 (2) 56-61}

setelah hampir semua daun menguning, demikian pula bulir padi sudah kering.

\section{Variabel Pengamatan}

Variabel pengamatan meliputi:

1. Analisis kandungan hara N,P dan K pada pupuk organik cair

2. Pertumbuhan dan Hasil tanaman padi meliputi tinggi tanaman diukur dari pangkal batang sampai ujung daun terpanjang, jumlah anakan total, jumlah malai, panjang malai, jumlah gabah bernas per malai, dan bobot 100 butir gabah kering.

\section{Hasil dan Pembahasan}

\section{Kandungan Nitrogen (N)}

Hasil Pengamatan kandungan $\mathrm{N}$ pada pupuk organik cair (Gambar 1) diketahui bahwa kandungan $\mathrm{N}$ tertinggi diperoleh pada perlakuan $\mathrm{C}$ (penambahan cangkang+daging keong mas) $(4,85 \%)$ dan terendah diperoleh pada perlakuan D (tanpa keong mas) $(1,83 \%)$. Hal ini mengindikasikan bahwa penambahan keongmas meningkatkan kandungan nitrogen pada pupuk cair yang dihasilkan hal ini disebabkan karena keongmas mengandung kitin yang cukup tinggi dan kitin ini berfungsi untuk meningkatkan kandungan nitrogen.

Berdasarkan hasil analisis kandungan Nitrogen pada pupuk organik cair keongmas diketahui bahwa pupuk yang dihasilkan memenuhi standar sesuai Standar Nasional Indonesia (SNI 19-7030-2004) untuk pupuk cair adalah sebagai berikut kandungan $\mathrm{N}>0,40 \%, \mathrm{P}$ $>0,10 \%$ dan kandungan $\mathrm{K}>0,20 \%$.

Menurut Parman (2007), nitrogen dalam pupuk organik cair berfungsi untuk menyusun protein yang berfungsi pada metabolisme tanaman yang selanjutnya akan memacu pembelahan dan pemanjangan sel. Semakin tinggi kandungan nitrogen pada bahan organik semakin baik pula bahan tersebut untuk digunakan sebagai pupuk.

Unsur Nitrogen dibutuhkan oleh tanaman dalam jumlah yang lebih banyak dari pada unsur hara lainnya, karena $\mathrm{N}$ sangat berperan dalam aktifitas fotosintesa sehingga berpengaruh pada pertumbuhan dan hasil tanaman (Ambarita, $d k k$ 2017).
e-ISSN : 2621-7236

p-ISSN : 1858-134X

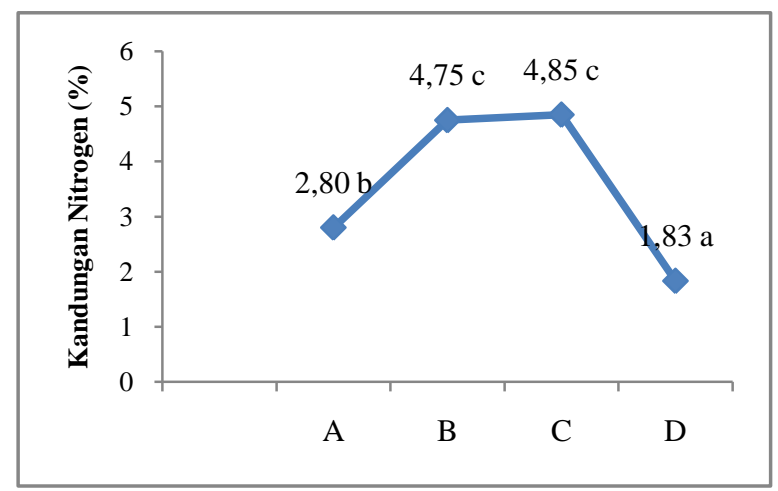

Gambar 1. Kandungan Nitrogen pada Pupuk Organik Cair

\section{Kandungan Fosfor (P)}

Hasil Pengamatan kandungan $\mathrm{P}$ pada pupuk organik cair (Gambar 2) diketahui bahwa kandungan $\mathrm{P}$ tertinggi diperoleh pada perlakuan $\mathrm{C}$ (penambahan cangkang+daging keong mas) $(0,77 \%)$ dan terendah diperoleh pada perlakuan A (penambahan cangkang keong mas) $(0,69 \%)$ tetapi tidak berbeda dengan perlakuan D (tanpa keong mas) $(0,70 \%)$ Hal ini mengindikasikan bahwa Penambahan keongmas meningkatkan kandungan $\mathrm{P}$ pada pupuk cair yang dihasilkan. Kandungan fosfor berkaitan dengan kandungan nitrogen dalam substrat, semakin besar nitrogen yang dikandung maka multiplikasi mikroorganisme yang merombak fosfor akan meningkat, sehingga kandungan fosfor dalam pupuk cair juga meningkat. Kandungan fosfor dalam substrat akan digunakan oleh sebagian besar mikroorganisme untuk membangun selnya. Proses mineralisasi fosfor terjadi karena adanya enzim fosfatase yang dihasilkan oleh sebagian besar mikroorganisme (Hidayati $d k k$., 2011).

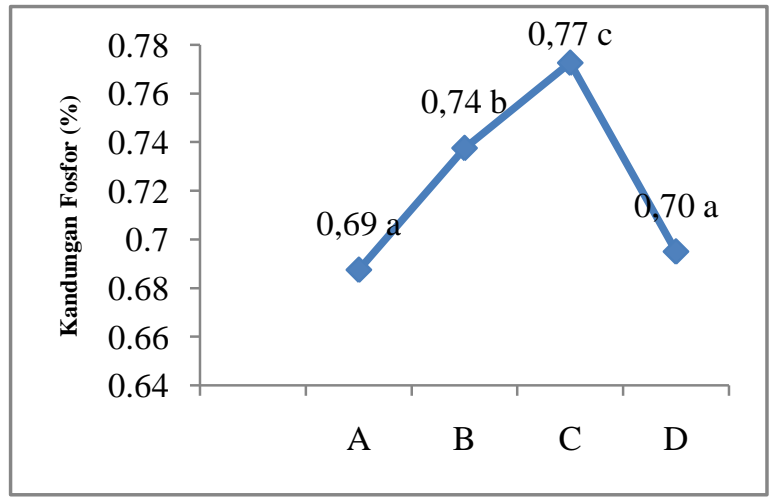

Gambar 2. Kandungan Fosfor pada Pupuk Organik Cair

\section{Kandungan Kalium (K)}

Hasil Pengamatan kandungan $\mathrm{K}$ pada pupuk organik cair (Gambar 3) diketahui bahwa kandungan $\mathrm{K}$ tertinggi diperoleh pada perlakuan B (penambahan daging keong mas) $(2,49 \%)$ dan 


\section{Jurnal Agrotech 8 (2) 56-61}

tidak berbeda dengan perlakuan A (penambahan cangkang keong mas) (2,47\%) dan C (penambahan cangkang dan daging keong mas) $(2,47)$. Sedangkan perlakuan terendah diperoleh pada perlakuan D (tanpa penambahan keong mas) $(2,03 \%)$ dan berbeda dengan perlakuan lainnya. Hal ini mengindikasikan bahwa Penambahan keongmas meningkatkan kandungan Kalium pada pupuk organik cair yang dihasilkan, namun pemberian keong mas baik dengan penambahan cangkang maupun penambahan daging keongmas tidak memberikan pengaruh yang berbeda terhadap nilai kandungan Kalium yang dihasilkan. Hal ini disebabkan karena kandungan kalium pada bagian cangkang maupun bagian daging tidak begitu berbeda. Pada pupuk organik cair yang tidak diberikan penambahan keong mas kandungan kaliumnya lebih sedikit dibandingkan dengan yang diberikan perlakuan keongmas, hal ini ada kaitannya dengan jumlah mikroba yang terdapat pada pupuk organik cair, dengan adanya penambahan keong mas maka jumlah mikroba juga meningkat karena keongmas dapat menghasilkan mikroba yang cukup tinggi. Hal ini sejalan dengan pendapat Hidayati (2011) yang mengatakan bahwa Kalium digunakan oleh mikroorganisme dalam bahan substrat sebagai katalisator, dengan kehadiran mikroba dan aktivitasnya akan sangat berpengaruh terhadap peningkatan kandungan kalium. Kalium diikat dan disimpan dalam sel oleh bakteri dan jamur, jika didegradasi kembali maka kalium akan menjadi tersedia kembali sehingga jumlahnya akan menjadi meningkat.

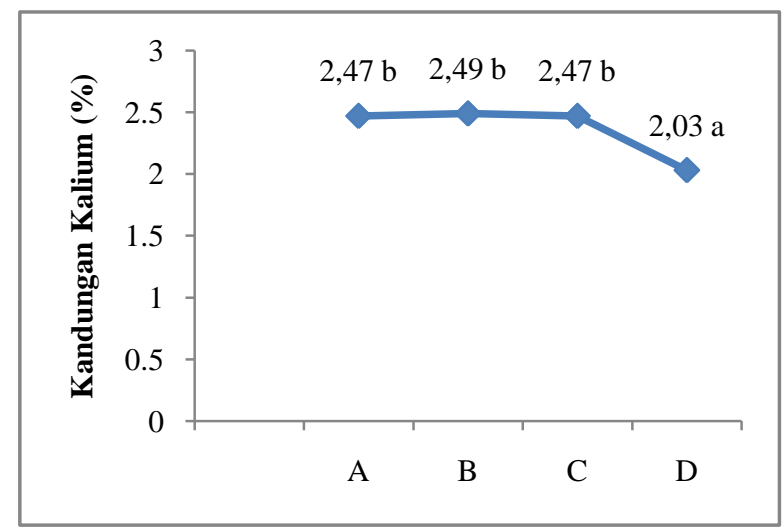

Gambar 3. Kandungan Kalium pada Pupuk Organik Cair

\section{Tinggi Tanaman}

Hasil uji statistik menunjukkan bahwa perlakuan pemberian pupuk organik cair keongmas tidak berpengaruh nyata terhadap tinggi tanaman padi. Hal ini disebabkan karena kandungan hara pada tanah masih tersedia masih mencukupi untuk pertumbuhan tanaman padi
e-ISSN : 2621-7236

p-ISSN : 1858-134X

pada stadia vegetatif, tinggi tanaman juga dipengaruhi oleh faktor genetik dari tanaman sehingga tidak terdapat perbedaan yang signifikan. Hal ini sejalan dengan pendapat Mildaerizanti, $d k k$ (2008), bahwa perbedaan tinggi tanaman lebih ditentukan oleh faktor genetik. Disamping dipengaruhi oleh faktor genetik, juga dipengaruhi oleh kondisi lingkungan tumbuh tanaman.

Pada umur 60 HST sampai pada umur 80 HST tanaman padi sudah tidak mengalami pertambahan tinggi tanaman hal ini disebabkan karena tanaman padi sudah memasuki fase generatif.

Tanaman padi membutuhkan unsur hara untuk memenuhi kebutuhan makanannya. Unsur hara yang diperlukan seperti unsur nitrogen, fosfor, kalium, serta karbon. Unsur-unsur tersebut dapat diperoleh melalui beberapa sumber, seperti udara, air, mineral-mineral dalam media tanam, dan pemberian pupuk (Leovini, 2012).

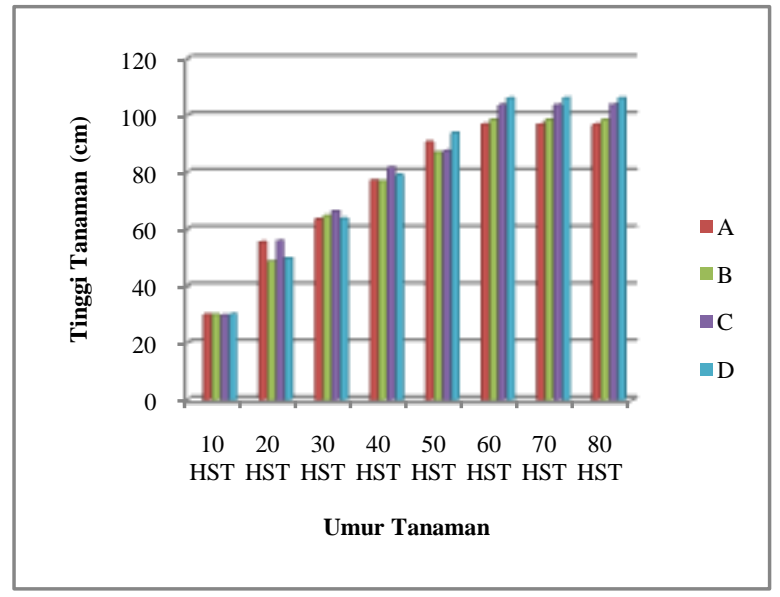

Gambar 4. Tinggi Tanaman Padi pada pemberian pupuk organik cair

\section{Jumlah Anakan Total}

Hasil uji statistik menunjukkan bahwa perlakuan pemberian pupuk organik cair keongmas berpengaruh sangat nyata terhadap jumlah anakan total tanaman padi. Hal ini disebabkan karena kandungan nitrogen yang terdapat pada pupuk organik cair keong mas memicu pertumbuhan tunas baru sehingga menghasilkan anakan yang lebih banyak. Hal ini sejalan dengan pendapat Azalika, dkk (2018) yang menyatakan bahwa Secara genetik varietas tanaman menentukan jumlah anakan dan peranan unsur $\mathrm{N}$ sangat penting dalam proses pertumbuhan jumlah anakan. 


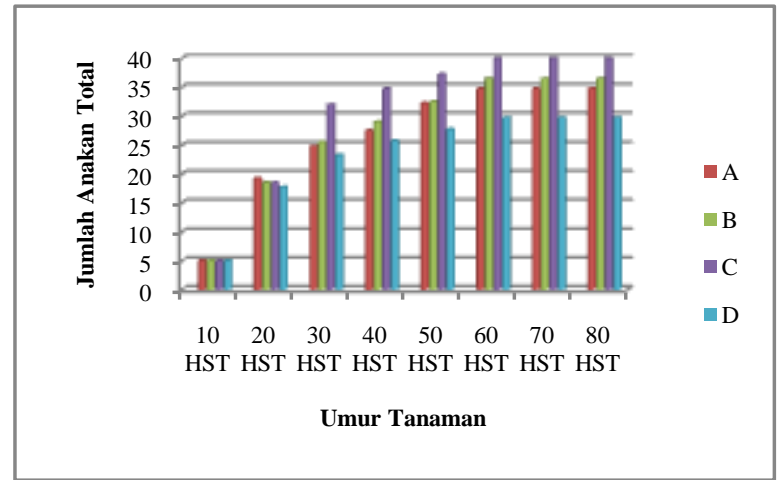

Gambar 5. Jumlah Anakan Total pada pemberian pupuk organik cair

\section{Jumlah Malai}

Hasil uji statistik menunjukkan bahwa perlakuan pemberian pupuk organik cair keongmas tidak berpengaruh terhadap jumlah malai tanaman padi. Hal ini disebabkan karena jumlah malai lebih dominan dipengaruhi oleh faktor genetik tanaman padi.

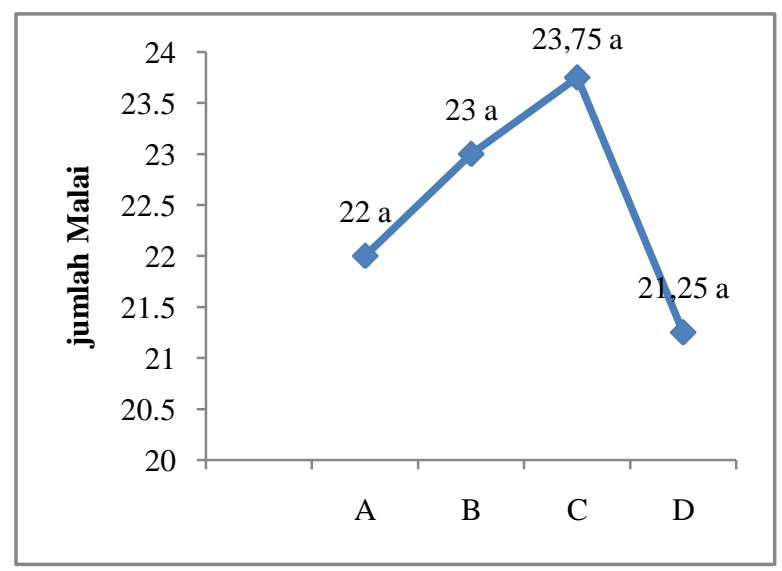

Gambar 6. Jumlah Malai Padi pada pemberian pupuk organik cair

\section{Panjang Malai}

Panjang malai merupakan komponen yang penting dalam penentuan hasil tanaman padi, semakin panjang malai maka diharapkan jumlah bulir juga semakin banyak. Namun pada penelitian ini hasil uji statistik menunjukkan bahwa perlakuan pemberian pupuk organik cair keongmas tidak berpengaruh nyata terhadap panjang malai tanaman padi. Hal ini disebabkan karena panjang malai lebih dominan dipengaruhi oleh faktor genetik tanaman sehingga tidak memberikan perbedaan yang signifikan. Hal ini sejalan dengan penelitian Zeani (2007) yang menyatakan bahwa pertumbuhan dan hasil tanaman padi dipengaruhi juga oleh faktor lingkungan dan faktor genetik tanaman.

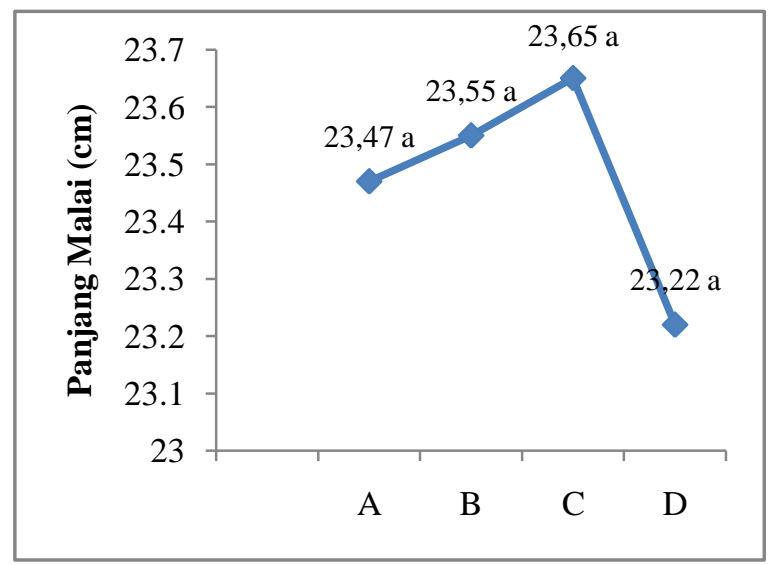

Gambar 7. Panjang Malai Padi pada pemberian pupuk organik cair

\section{Jumlah Biji Bernas}

Hasil uji statistik menunjukkan bahwa perlakuan pemberian pupuk organik cair keongmas berpengaruh sangat nyata terhadap jumlah biji bernas permalai tanaman padi. Jumlah biji bernas permalai (Gambar 8) tertinggi diperoleh pada perlakuan $\mathrm{C}$ (penambahan cangkang+daging keong mas) dan berbeda nyata dengan perlakuan lainnya. Hal ini disebabkan karena hara yang dibutuhkan untuk perkembangan tanaman selama pertumbuhan generatif dan untuk berlangsungnya proses fotosintesis dapat dipenuhi. Sedangkan jumlah biji bernas permalai terendah diperoleh pada perlakuan D (tanpa penambahan keong mas) hal ini disebabkan karena pada perlakuan D terdapat banyak gabah hampa, dibandingkan dengan perlakuan yang lainnya. Hal ini disebabkan karena kandungan N,P, dan K pada perlakuan D lebih kecil sehingga terjadi kompetisi hara antar tanaman yang menyebabkan terjadinya penurunan laju fotosintesis dan translokasi fotosintat yang mengakibatkan proses pengisian hasil fosintesis saat masak susu (milk stage) tidak berlangsung sempurna ke semua biji yang terbentuk di malai sehingga menyebabkan jumlah gabah hampa lebih tinggi. Hal ini berarti bahwa perlakuan nyata memberikan pengaruh terhadap jumlah biji bernas permalai, semakin tinggi kandungan N,P, dan $\mathrm{K}$ pada pupuk cair maka semakin sempurna proses pengisian biji. Hal ini sejalan dengan pernyataan Abdulrachman (2009), kekurangan unsur $\mathrm{K}$ dapat menyebabkan kehampaan gabah tinggi dan pengisian gabah tidak sempurna. 


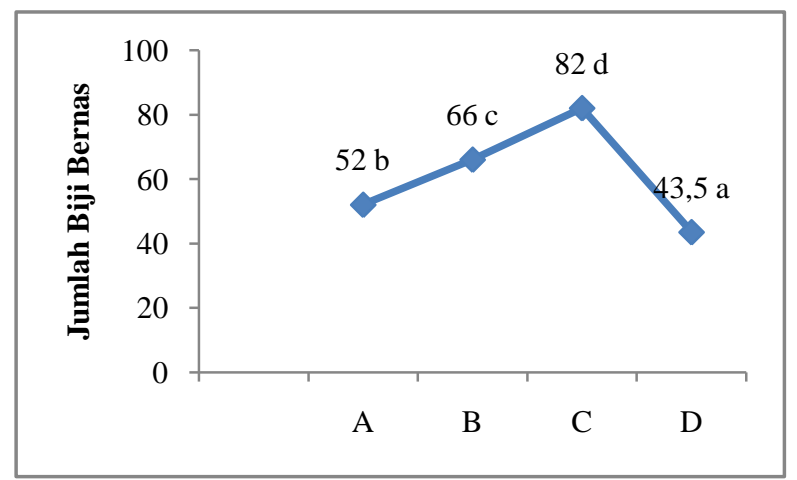

Gambar 8. Jumlah Biji Bernas pada pemberian pupuk organik cair

\section{Berat biji per 100 biji}

Hasil uji statistik menunjukkan bahwa perlakuan pemberian pupuk organik cair keongmas berpengaruh sangat nyata terhadap berat biji per 100 biji gabah kering tanaman padi. Berat biji per 100 biji gabah kering (Gambar 9) tertinggi diperoleh pada perlakuan C (penambahan cangkang+daging keong mas) dan berbeda nyata dengan perlakuan lainnya. Berat biji per 100 biji gabah kering terendah diperoleh pada perlakuan D (tanpa penambahan keong mas) dan berbeda nyata dengan perlakuan lainnya. Semakin tinggi kandungan N,P, dan K pada pupuk cair yang diberikan maka berat biji akan semakin meningkat hal ini berarti bahwa pupuk organik cair yang diberikan menyediakan unsur hara yang cukup untuk memenuhi syarat pertumbuhan dan hasil tanaman padi, sehingga pengisian bulir padi menjadi maksimal dan menghasilkan biji padi yang lebih berat. Hal ini sejalan dengan penelitian Zahra (2012) yang mengemukakan bahwa peningkatan berat kering gabah dan berat 1000 biji tanaman padi adalah berkaitan dengan meningkatnya serapan hara $\mathrm{N}$, $\mathrm{P}$, dan $\mathrm{K}$ tanaman akibat pemberian pupuk bokashi dan NPK organik. Suplai unsur hara yang cukup akan menunjang pertumbuhan tanaman dan menghasilkan produksi yang lebih tinggi.

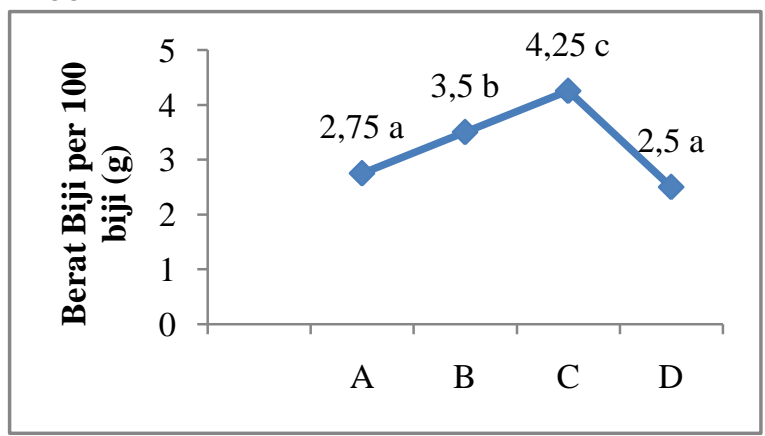

Gambar 9. Berat biji per 100 biji gabah kering tanaman padi pada pemberian pupuk organik cair

\section{Kesimpulan}

1. Perlakuan penambahan daging dan cangkang keong mas memberikan hasil tertinggi terhadap kandungan hara $\mathrm{N}, \mathrm{P}$, dan K pupuk organik cair.

2. Pemberian Pupuk Cair keong mas dapat meningkatkan pertumbuhan dan hasil tanaman padi yang berupa jumlah anakan, panjang malai, jumlah biji bernas dan bobot biji.

\section{Daftar Pustaka}

Abdulrachman, S., Sembiring, H., dan Suyamto. 2009. Pemupukan Tanaman Padi.www.litbang.pertanian.go.id

Ambarita Y, Hariyono D, dan Aini N, 2017. Aplikasi Pupuk NPK dan Urea pada Padi (Oriza sativa L) Sistem Ratun. Jurnal Produksi Tanaman. Vol 5(7) 1228-1234.

Arsyadana, 2014. Efektivitas Biopestisida Biji Mahkota Dewa (Phaleria acrocarpa) dengan Lama Fermentasi yang Berbeda untuk Mengendalikan Hama Keong Mas (Pomacea Canaliculata) Pada Tanaman Padi Jurnal Penelitian. Universitas Muhammadiyah Surakarta.

Azalika, R.P., Sumardi, Sukisno, 2018. Pertumbuhan dan Hasil Padi Sirantau Pada Pemberian Beberapa Macam Dan Dosis Pupuk Kandang. Jurnal Ilmu-Ilmu Pertanian Indonesia. Fakultas Pertanian. Universitas Bengkulu. Bengkulu.

Hidayati Y.A., Kurnani B.A., Marlina E.T., dan Harlia E., 2011. "Kualitas Pupuk Cair Hasil Pengolahan Feses Sapi Potong Menggunakan Saccharomices cereviceae". Jurnal Penelitian.

Leovini, H. 2012. Pemanfaatan Pupuk Organik Cair pada Budidaya Tanaman Tomat (Solanum lycopersicum L.). Jurusan Budidaya Pertanian, Fakultas Pertanian Universitas Gadjah Mada.

Mildaerizanti, Hernita, D., Salwati dan Murdelulono, 2008. Keragaan Beberapa Varietas Padi Gogo Di Daerah Aliran Sungai Batanghari.

Parman, S. (2007). Pengaruh Pemberian Pupuk Organik Cair Terhadap Pertumbuhan dan Produksi Kentang (Solanum tuberosum). Buletin Anatomi dan Fisiologi.

Sulfianti., 2013. Pengaruh Kondisi dan Lama Fermentasi terhadap Kualitas Ekstrak Organik Cair yang diaplikasikan pada Tanaman Bayam (Amaranthus sp). Tesis. Palu : Program Pascasarjana Universitas Tadulako. 